NBER WORKING PAPER SERIES

U.S. GROWTH IN THE DECADE AHEAD

Martin S. Feldstein

Working Paper 15685

http://www.nber.org/papers/w15685

\author{
NATIONAL BUREAU OF ECONOMIC RESEARCH \\ 1050 Massachusetts Avenue \\ Cambridge, MA 02138 \\ January 2010
}

The views expressed herein are those of the author and do not necessarily reflect the views of the National Bureau of Economic Research.

NBER working papers are circulated for discussion and comment purposes. They have not been peerreviewed or been subject to the review by the NBER Board of Directors that accompanies official NBER publications.

(C) 2010 by Martin S. Feldstein. All rights reserved. Short sections of text, not to exceed two paragraphs, may be quoted without explicit permission provided that full credit, including $\odot$ notice, is given to the source. 
U.S. Growth in the Decade Ahead

Martin S. Feldstein

NBER Working Paper No. 15685

January 2010

JEL No. E2

\begin{abstract}
This paper examines the likely growth of U.S. GDP in the decade beginning in 2010. I analyze the two components of the rise in GDP over this ten year period: (1) the recovery from the substantially depressed level of economic activity at the start of the decade; and (2) the rise in potential GDP that will result from the expansion of the labor force, the growth of the capital stock, and the increase of multifactor productivity. I calculate a likely growth rate of 2.6 percent a year.

Not all of that extra output will remain in the United States. If the trade deficit is reduced by three percent of GDP, the rise in exports and decline in imports will reduce output available for U.S. consumption and investment by about 0.3 percent a year.

The effect of a decline of the dollar could be equally important. If the real trade-weighted value of the dollar declines by 25 percent over the decade and the full effect of that dollar decline is reflected in the prices of imports, the increased cost of imports would reduce the the growth of our real incomes by about 0.4 percent a year.

These two international effects would leave the net growth of real goods and services available for US consumption and investment -- both domestically produced and imported -- at 1.9 percent a year. That is the same as the average growth during the past decade.
\end{abstract}

\author{
Martin S. Feldstein \\ President Emeritus \\ NBER \\ 1050 Massachusetts Avenue \\ Cambridge, MA 02138-5398 \\ and NBER \\ msfeldst@nber.org
}




\section{U.S. Growth in the Decade Ahead}

Martin Feldstein ${ }^{1}$

The beginning of 2010 is a good time to consider the likely pace of growth during the decade ahead. It is of course not clear how the economy will behave in the current year, let alone in the coming ten years. The rise of GDP that began in the third quarter of 2009 was not an ordinary cyclical recovery. The economy's growth in the second half of last year was driven by a strong fiscal stimulus, including not only increased federal spending and transfers but also special subsidies to car buyers and to first time home buyers. Home buying was also stimulated by the sharp drop in mortgage rates that increased the number of individuals who could qualify for mortgages on properties that they liked. These forms of stimulus will be missing in 2010, creating a serious cloud over the near-term economic outlook.

Looking further ahead, it will be difficult to have a robust recovery as long as the residential and commercial real estate markets are depressed and the local banks around the country restrict their lending because of their concern about possible defaults on real estate loans. Any economic expansion could also be suppressed if the enormous fiscal deficits projected for the coming decades lead to rising long term real interest rates.

But while mindful of all of these near-term risks, I will make the optimistic but plausible assumption that the economy will fully recover over the next ten years. With that assumption, we can usefully decompose the projected GDP growth over the next decade into the cyclical recovery and the evolution of potential GDP. While potential GDP is likely to rise more slowly than in the decade that just ended, my calculations imply that the economic recovery as such will raise the rate of GDP growth by more than enough to outweigh the slowdown in the growth of potential GDP. That extra rise in output will, however, be offset by the likely effect of the falling dollar and the shrinking trade deficit. In the end, the rise in available real

\footnotetext{
${ }^{1}$ Professor of Economics, Harvard University. This paper was prepared for presentation at the American Economic Association meeting on January 3, 2010 in a session on The Risk of Post-recession Stagnation.

(USGrowthintheDecade)
} 
domestic resources in the decade ahead looks like it will be very similar to the experience of the past decade.

The increased pace of GDP growth that will be caused by the recovery of demand will reflect the serious deepness of the hole in which the U.S. economy now finds itself. Economic growth will rise more rapidly than in the past as the labor market returns to full employment, as the labor force participation rate rises, and as capacity utilization returns to normal.

But the decade ahead will also be a time in which the labor force will grow more slowly than it did in the past and in which both capital accumulation and multi-factor productivity are also likely to grow more slowly.

In these brief remarks I will try to quantify these likely developments, recognizing that many uncertainties remain about each of them. I will also consider the impact on the U.S. standard of living of the potential changes in the trade balance and in the real exchange rate.

\section{Cyclical Recovery}

The cyclical recovery will bring the unemployment rate from the current 10 percent of the labor force to something closer to five percent. The rising demand for labor will also reverse the cyclical fall in the labor force participation rate from the 66.1 percent before the recession began to the current 65.0 percent. This combined cyclical recovery of the labor force would be equivalent to an employment rise of 4.3 percent of the population or a fall in the unemployment rate equal to 6.5 percent of the current labor force.

Okun's law provides a plausible if not always accurate way of translating this cyclical change in unemployment to a rise in GDP. Even a conservative Okun's law ratio of a 2 percent change of GDP per point of unemployment implies a cyclical rise of real GDP of 13 percent over the next decade or an average of 1.2 percent per year.

In contrast, during the past decade the unemployment rate rose from 4.0 percent to 10 percent and the labor force participation rate fell from 67.1 percent to 65.0 percent. The combined fall in employment as a share 
of the population is equivalent to an 8.9 percent rise in the unemployment rate. If that entire change in unemployment can be regarded as cyclical, Okun's law implies that there was a cyclical fall of real GDP over the decade of 17.8 percent or 1.6 percent per year.

If the economy gets back to full employment by the end of the current decade and the Okun's law relation continues to hold, real GDP will rise by 1.2 percent a year on top of the rise in potential GDP, a sharp improvement from the 1.6 percent a year cyclical decline in the past decade.

\section{Changes in Potential GDP Growth}

The future path of potential GDP is not likely to be as good as the path of potential GDP in previous decades. The rise of potential GDP has three basic components: the rise of the labor force, the increase in the capital stock, and the rise in multifactor productivity.

\section{The Labor Force}

The rise of the labor force depends on population growth and changes in the labor force participation rate. The Bureau of Labor Statistics (BLS) of the U.S. Department of Labor predicted last month that the coming decade will see slower population growth and a declining labor force participation rate. The BLS predicts that the labor force will grow by only 8.2 percent between 2008 and 2018, down from the 12.1 percent rise in the previous ten years.

Measuring the labor force in this way ignores important aspects of human capital, including the age structure, education, and occupational mix of the labor force. The BLS notes, for example, that the labor force will be older and that a primary focus of employment growth will be in health care and "social assistance" occupations.

But if we focus just on the numbers in the labor force, a simple CobbDouglas technology with a labor coefficient of two-thirds implies that the slower growth of the labor force will reduce the rise in potential GDP over the decade to an increase of about 0.5 percent a year, down by about 0.26 percent a year from the previous decade. 


\section{The Capital Stock}

It is more difficult to predict the changing growth of the capital stock and its implications for the future rise of GDP. The growth of the capital stock will depend on the saving behavior of households and firms, on the size of the future fiscal deficit, and on the inflow of capital from abroad. Let's look at each of these in turn.

Households have recently been raising their saving rates to rebuild the net worth that was destroyed by the decline in the stock market and in home prices. The saving rate as a percentage of disposable personal income rose from less than two percent in 2007 to between four and five percent in recent months. It is not clear whether this rising trend will continue in the next few years since overall household saving may be temporarily depressed by the unemployed individuals who reduce their saving in order to maintain their consumption. But as employment rises later in the decade we should expect to see an increasing share of income going into a higher saving rate.

It is useful in this context to remember that, in the quarter century after 1960, the U.S. household saving rate varied between 7 percent and 11 percent, averaging 9.2 percent of disposable personal income or about 7 percent of GDP.

Corporate saving (i.e., undistributed corporate profits) increased sharply in the first three quarters of 2009 , returning to the pre-recession level of 2006, but is still only about 3 percent of GDP.

Combining household and corporate saving implies that private saving might increase during the current decade to as much as 10 percent of GDP. But if the personal saving rate stays at its current level of about 4.5 percent of disposable income or about 3 percent of GDP, total private saving would be only about 6 percent of GDP.

The final piece of national saving is the government surplus or, more accurately, the government deficit that reduces total national saving. The future evolution of the fiscal deficit is impossible to predict without knowing how the administration and Congress will respond to the current projected large deficits. But it is worth noting that the IMF's World Economic Outlook recently predicted that the US fiscal deficit will fall from 10 percent of GDP 
in the current fiscal year to 6 percent in 2012 and will then remain in the 6 to 7 percent range for the rest of the decade. Such enormous sustained deficits would exceed anything that has occurred since World War II.

These projected fiscal deficits could completely absorb all of the private saving, leaving no national saving to finance additions to the capital stock. If that happens, all net investment in plant and equipment and in housing would have to be financed by capital inflows from abroad.

Although the net capital inflows to the United States from the rest of the world (i.e., the U.S. current account deficit) have averaged 5 percent of U.S. GDP during the past five years, there is reason to believe that the volume of inflows will decrease in the years ahead. At the recent G20 meeting, the U.S. and other nations agreed that such global imbalances should be reduced. China, the largest source of the capital inflow to the U.S., is taking steps to shift from export led growth to a greater emphasis on domestic demand. In addition, many countries want to shift the mix of currencies in their foreign exchange investments away from dollars. So while it is impossible to predict precisely what will happen to the available inflow of capital from abroad, it seems likely that the flow of capital to the U.S. will be smaller in the future than it has been in the past decade.

Changes in the national saving rate and in the capital inflow from abroad will change the capital stock only slowly. The impact of this on GDP is therefore not likely to be large during the coming decade but could have a much larger cumulative effect if a decline continues beyond the current decade. The changing composition of the capital stock, with a greater emphasis on information technology equipment and software, may imply rates of return that offset some of the potential decline in the total dollar size of the capital stock.

\section{Multifactor Productivity}

In addition to the slower growth of the labor force and the uncertain change in the size of the capital stock, the change in potential GDP will depend on what happens to the rate of change of multifactor productivity. According to the OECD, US multifactor productivity rose at a relatively stable rate of about 0.75 percent a year from 1985 to 2000 (i.e., at 0.7 percent a year from 1985 to 1990, at the same rate from 1990 to 1995, and 
at 0.9 percent from 1995 to 2000) and then increased to a 1.4 percent a year rate from 2001 through 2008. There is no way to know whether the increase of multifactor productivity growth will remain at its current level of will revert to the lower pace of the years before 2000 .

\section{Combined Effect on Potential GDP}

In summary, if the slower growth of the labor force reduces the annual GDP increase by the 0.26 percent calculated above, if there is no rise in productivity due to capital accumulation, and if the multifactor productivity declines to its pre-2000 average, the annual rate of growth of potential GDP will decline by about 0.9 percent to 1.4 percent a year. Combining these conservative assumptions about potential GDP with the effect of the cyclical rebound -- an estimated 1.2 percent a year cyclical rise in real GDP -- would produce a total real GDP increase at a rate of 2.6 percent. If this occurs, it would be a significant increase from the 1.9 percent annual rate of increase of real GDP in the decade ending in 2009.

\section{The Trade Deficit and the Dollar}

But the rise in real GDP is only part of the story of what will happen to real domestically available income over the coming decade. Even if the amount of GDP produced in the United States rises at a rate of 2.6 percent, not all of that extra output will remain in the United States. If we shrink our trade deficit over the decade by three percent of GDP, the rise in exports and decline in imports will reduce the rise of output available for U.S. consumption and investment by about 0.3 percent a year.

The effect of a decline of the dollar could be equally important. The real trade-weighted value of the dollar fell some 25 percent between 2002 and 2008, before it rose temporarily as nervous investors world-wide rushed to buy short term US Treasuries. It is of course impossible to predict the path of the dollar over the coming decade. But consider the effect if the dollar does fall another 25 percent as part of the process of shrinking the U.S. trade deficit and that the full effect of that dollar decline is reflected in the price of imports, no doubt a simplification.

Since the U.S. imports of goods and services are usually about 17 percent of US GDP (although recently reduced by the recession), a 25 percent fall of the dollar would raise the cost of imports by about 4 percent 
of GDP. So when Americans trade U.S. production for foreign goods, the 17 percent of GDP that we spend on imports will buy about 4 percent less in real terms. This in effect reduces the growth of our real incomes by about 0.4 percent a year.

The combined effect of a reduced trade deficit ( 0.3 percent fewer goods and services available in the U.S. each year) and of the higher price of imports (equivalent to a 0.4 percent of GDP decline in the real volume of goods and services that Americans can obtain by their spending on imports ) would reduce the growth of real domestically available GDP by 0.7 percent a year over the coming decade, a significant reduction of the 2.6 percent projected growth of real GDP output. The net annual rate of increase in the total real goods and services available for US consumption and investment -- both domestically produced and imported -- would therefore be only 1.9 percent a year.

Comparison with the Previous Decade

Real GDP, as conventionally measured in the national income and product accounts, rose by 21 percent between 1999 and 2009, an annual rate of increase of 1.9 percent.

During that same decade the U.S. trade deficit went from 2.8 percent of GDP in 1999 to 4.8 percent in 2008 (before the recession depressed imports), expanding the physical volume of goods and services available in the United States by 2 percentage points. But the decade also experienced a 13 percent fall in the real trade weighted value of the dollar, increasing the cost of imports by about 2 percent of GDP. These two effects cancelled each other out, leaving the the estimated real usable rise in domestically available GDP at 1.9 percent a year.

Surprisingly, this is the same rate of growth of domestically available GDP that my calculations imply for the decade ahead.

Cambridge, MA

December 2009 